\title{
Výsledky pilotní studie dotazníku SE-PETE-D, který zjišt'uje důvěru studentů učitelství tělesné výchovy $v$ jejich kompetence $k$ realizaci výuky integrované tělesné výchovy
}

\section{The results of the pilot study of questionnaire SE-PETE-D, which checks the trust of students of physical education teacher in their competence to implement classes in an integrated physical education}

\author{
Ladislav Baloun, Martin Kudláček, Ondř̌j Ješina \\ Fakulta tělesné kultury, Univerzita Palackého v Olomouci, \\ Olomouc, Česká republika
}

Abstrakt:

Účelem práce je představení dotazníku Self-Efficacy Scale for Physical Education Teacher Education Majors towards Children with Disabilities (SE-PETE-D), který chceme v budoucnu využít v České republice ke zjištování self-efficacy pro v práci integrované tělesné výchově u studentů učitelstvi tělesné výchovy. Zároveň budou také prezentovány výsledky pilotni studie restandardizace tohoto dotazniku v podmínkách českého prostředí. Kličovým pojmem, se kterým dotazník pracuje, je self-efficacy, a zavedl ho kanadsko-americký psycholog Albert Bandura (1997). Pilotni studie se zúčastnili studenti navazujicího magisterského studia voboru aplikovaná tělesná výchova. Komparace se zúčastnili studentibakalářského studia učitelstvítělesnévýchovy, studentibakalářského studia aplikovaná tělesná výchova. Porovnání skupin proběhlo za pomoci t-testu. $Z$ výsledků vyplývá, že studenti aplikovaných pohybových aktivit 
maji vyšši self-efficacy pro práci v integrované tělesné výchově, než studenti učitelství tělesné výchovy.

\section{Abstract:}

The purpose of this work is the presentation of the questionnaire of the Self-Efficacy Scale for Physical Education Teacher Education Majors towards the Children with Disabilities (SE-PETE-D), which should be used in the future to identify self-efficacy of the students of the teacher training in physical education. At the same time will be also presented the results of a pilot study of standardization of this questionnaire in the conditions of the Czech environment. A key concept of questionnaire is self-efficacy. and introduced its the Canadian-American psychologist Albert Bandura (1997). A pilot study and comparison encompass bachelor students took part in the teaching of physical education, students of bachelor studies in adapted physical education and students of the follow-up master degree in adapted physical education. The results show that students of bachelor studies in adapted physical education have higher self-efficacy than students of bachelor studies in physical education.

Klíčová slova: self-efficacy, integrace, tělesná výchova, osoby se zdravotním postižením.

Key words: self-efficacy, integration, physical education, people whit disabilities.

Tento př́spěvek vznikl v rámci projektu IGA: FTK_2013:012 s názvem Kompetence studentů učitelství tělesné výchovy ve vztahu k práci v integrované tělesné výchově. 
The results of the pilot study of questionnaire SE-PETE-D, which checks the trust of students of physical education...

Výsledky pilotní studie dotazníku SE-PETE-D, který zjištuje důvěru studentů učitelství tělesné výchovy v jejich...

\section{ÚVOD}

Vztah člověka a společnosti k osobám s postižením je podle Vágnerové, Hajd-Moussové a Štecha (2001) výrazem tolerance k odlišnosti a respektování individuality. Zároveň je to také výraz vnitřní kvality daného člověka a komunity. Budou-li společnost a její jednotliví členové schopni překročit konvence a stereotypy, pak nebudou osoby s postižením vnímány pouze pod zorným úhlem postižení, at' už s odmítáním nebo se soucitem. Každý člověk, bez ohledu na jeho odlišnost, musí být chápán jako člověk se specifickými kvalitami. Společenské vnímání osob s postižením založené na předsudcích a stereotypech je možné překonat především, pokud se podaří rozbít bariéry, které dělí osoby s postižením od ostatní společnosti. Umožní se tak vzájemnému kontaktu a poznání, např́iklad prostřednictvím integrace dětí s postižením do běžných škol, při zachování nutné speciálně pedagogické péče (Vágnerová, HajdMoussová \& Štech 2001).

Je všeobecně známo, že vhodná a přiměřená pohybová aktivita přispívá ke zlepšení a upevnění zdraví člověka. Nutné je však zdůraznit aspekt sociální a psychický, a to zejména v oblasti rozvoje poznávacích procesů (Karásková, 2005). To samožrejmě platí i pro osoby se zdravotním postižením. Podle Votavy (2003) je význam pohybových aktivit a sportu pro osoby se zdravotním postižením v oblasti zdokonalování obratnostních schopností a získávání nových dovedností, udržování a zlepšování tělesné kondice a sociálních vazeb v rámci výchovně-vzdělávacího procesu nebo při vylepšování volného času. Kursová (2009) poukazuje na to, že během sportovní činnosti si osoby se zdravotním postižením osvojují a zvykají na nové sociální role, které vyžadují spolupráci, tvořivost a překonávání nejrůznějších zábran.

U tělesně postižených žáků dochází v posledních letech $\mathrm{k}$ větší mírue začleňování do škol běžného typu. Podle statistik Ústavu pro informace ve vzdělávání pro školní rok 2011/2012 (dostupné na http://toiler.uiv.cz/ rocenka/rocenka.asp) se počet integrovaných žáků s tělesným postižením na základních a středních školách pohybuje okolo 1400 . Obecně se předpokládá, že není-li snížen intelekt zdravotně postižených žáků, ne- 
existuje na školách př́liš mnoho problémů se začleňováním do běžného kolektivu i vzdělávacích předmětů. V oblasti tělesné výchovy však narazíme na problémy, které vycházejí z charakteru postižení a náplně hodin školní tělesné výchovy (Kudláček, 1997). V této situaci je učitel tělesné výchovy postaven před velmi náročný úkol, jak smysluplně a bezpečně začlenit žáka se zdravotním postižením do hodin školní tělesné výchovy, aniž by to negativním způsobem ovlivnilo průběh výuky tělesné výchovy pro intaktní žáky. Se zavedením pojmu integrace ve školní tělesné výchově vznikla potřeba řešit nastalé problémy, vyplývající z náročnosti praktikovat integrovanou výuku. Podle výzkumného zjištění (Spurná, Rybová \& Kudláček, 2010) převládá mezi některými současnými učiteli tělesné výchovy názor, že nejsou dostatečně vybaveni kompetencemi $\mathrm{k}$ vedení hodin integrované tělesné výchovy, nedisponují potřebnými znalostmi, což může mít za následek jejich odmítavý postoj k integraci jako takové. Tito pedagogové se shodují na těchto faktech. Mají strach s dítětem se zdravotním postižením cvičit, aby se mu něco nestalo; nevědí, jaký by měl být obsah hodin tělesné výchovy; nevědí, jak vytvořit vyučovací hodinu zajímavou pro všechny děti; postrádají základní literaturu na toto téma (Čurdová, 2002, 116). Z tohoto důvodu byly do kurikul některých vysokých škol (jde např́klad o pedagogické fakulty na Západočeské univerzitě v Plzni, Jihočeské univerzitě v Českých Budějovicích a na Univerzitě J. E. Purkyně v Ústí nad Labem, dále pak o Fakultu tělesné výchovy a sportu na Karlově univerzitě v Praze, Fakultu sportovních studií na Masarykově univerzitě v Brně a Fakultu tělesné kultury Univerzity Palackého v Olomouci), které vzdělávají budoucí učitele školní TV, zavedeny předměty, jejichž obsah je zaměřen na seznámení se s pohybovými aktivitami pro osoby se zdravotním postižením a možnostmi, jak integrovat tyto žáky do hodin TV (Válková, 2011).

\section{CÍLE PRÁCE}

Cílem práce je představení dotazníku Self-Efficacy Scale for Physical Education Teacher Education Majors towards Children with Disabilities (SE-PETE-D), který by měl být v budoucnu využit ke zjišt'ování 
The results of the pilot study of questionnaire SE-PETE-D, which checks the trust of students of physical education...

Výsledky pilotní studie dotazníku SE-PETE-D, který zjištuje důvěru studentů učitelství tělesné výchovy v jejich...

self-efficacy pro realizaci výuky školní integrované tělesné výchovy studentů u učitelství tělesné výchovy. Zároveň budou také prezentovány výsledky pilotní studie standardizace tohoto dotazníku v podmínkách českého prostředí.

\section{HYPOTÉZA}

Při komparaci výsledků pilotní studie byla stanovena následující hypotéza: Studenti aplikovaných pohybových aktivit budou mit vyšši self-efficacy pro realizaci výuky integrované tělesné výchovy (se zaměrením na osoby s mentálním, tělesným a zrakovým postižením) než studenti tělesné výchovy.

\section{METODIKA}

V České republice chceme použít dotazník SE-PETE-D ke zjištování a popsání self-efficacy pro realizaci výuky integrované tělesné výchovy u studentů učitelství tělesné výchovy na vybraných vysokých školách. Před zmíněnou činností je potřeba dotazník SE-PETE-D restandardizovat v České republice.

Prvním krokem potřebným pro restandardizaci dotazníku byla jeho translace $z$ anglického do českého jazyka, přičemž byla využita procedura standardní zpětné translace, kterou popisují Banville, Desroisiers a Genet-Volet (2000). Tato metoda vychází z techniky mezikulturní translace, kterou navrhl Vallerand (1989).

Dalším provedeným krokem bylo posouzení expertní validity. Nezávisle na sobě byli osloveni tři experti z oboru kinantropologie se zaměřením na aplikované pohybové aktivity. Následovalo ověření srozumitelnosti položek na pilotním vzorku. Respondenty tvořila skupina 14 (11 žen a 3 muži) studentů druhého ročníku navazujícího magisterského studia v oboru aplikovaná tělesná výchova. Při testování se sledoval čas potřebný pro vyplnění dotazníku a srozumitelnost celého textu a jednotlivých položek. Dále byl zahájen pilotní sběr dat, jehož se zúčastnilo celkem 42 studentů bakalářského studia na Fakultě tělesné kultury Univerzity Palackého v Olomouci. Byli to studenti prvních, druhých a tře- 
tích ročníků. Zkoumaná skupina byla rozdělena na dvě části podle zaměření studia. První skupinu tvořili studenti studijních oborů aplikovaná tělesná výchova a aplikované pohybové aktivity (dále jen studenti APA). Druhou část tvořili studenti oboru učitelství tělesné výchovy (dále jen studenti TV). Pro statistické zpracování nebylo z důvodů nekompletního vyplnění dotazníku připuštěno celkem 7 vzorků. To znamená, že statisticky zpracovány byly výsledky od 21 (15 žen a 6 mužủ) studentů APA a 14 (8 žen a 6 mužů) studentů TV.

Srovnávány byly průměrné hodnoty obou sledovaných skupin, přičemž každá položka zjišt'ující úroveň self-efficacy je vyhodnocena samostatně. Statistické zpracování bylo provedeno na softwaru SPSS 20.0.

\section{VÝSLEDKY}

\section{Představení dotazníku SE-PETE-D}

Standardizovaný dotazník SE-PETE-D (Block, et al., 2013), který pracuje s pojmem self-efficacy, se snaží zjistit sebedůvěru ve vlastní schopnosti studentů učitelství tělesné výchovy při snaze o integraci osob se zdravotním postižením do hodin školní tělesné výchovy.

Klíčovým pojmem, se kterým dotazník pracuje, je self-efficacy. Koncept self-efficacy (podrobně v Bandura, 1997) má základy ve velkém teoretickém rámci známém jako sociálně-kognitivní teorie (podrobně v Bandura, 1989) a zavedl ho kanadsko-americký psycholog Albert Bandura. Pojem self-efficacy se do češtiny př̀kládá jako sebeuplatnění (Janoušek, 1992), vnímané sebeuplatnění (Janoušek, 2006), pojetí vlastní obecné efektivity (Nakonečný, 1998), vědomí vlastní účinnosti (Blatný a kol., 2010), di̊věra ve vlastní zdatnost $\mathrm{v}$ českém překladu knížky Psychologie sportu (Tod et. al., 2012), nebo také podle Urbánka a Čermáka (1997) doslovným překladem sebeúčinnost. Vzhledem k nejednoznačnosti překladu pojmu self-efficacy z anglického do českého jazyka, na který upozorňuje i Blatný a kolektiv (2010), se autoři tohoto textu rozhodli používat anglický název self-efficacy.

Podle Bandury (1997) je self-efficacy popisována jako míra schopností, kterou si člověk přisuzuje a která určuje důležitou složku psychiky 
The results of the pilot study of questionnaire SE-PETE-D, which checks the trust of students of physical education...

Výsledky pilotní studie dotazníku SE-PETE-D, který zjištuje důvěru studentů učitelství tělesné výchovy v jejich...

a očekávání, nebo jinak také víru ve vlastní schopnosti dosáhnout určených úrovní výkonu. To se uplatňuje tak, že se člověk ujímá takových úkolů a vstupuje do takových situací, o nichž se domnívá, že je svými schopnostmi zvládne. Ostatním úkolům a situacím, o kterých se domnívá, že je nezvládne, se vyhýbá. Víra ve vlastní schopnosti pomáhá člověku překonat těžkosti, a tak souvisí s mírou vynakládaného úsilí. Síla této víry souvisí s minulými úspěchy a neúspěchy a je více či méně generalizována či diferencována. Self-efficacy však nevyrůstá pouze ze schopnosti. Být něčeho schopen neznamená ještě být přesvědčen o tom, že jedinec je něčeho schopen. Self-efficacy je produktem komplexních procesů kognitivního zpracování různých zdrojů informací relevantních pro sebeúčinnost, a je zprostředkováno přímým i zástupným působením a fyziologickou zpětnou vazbou.

Do kontextu aplikovaných pohybových aktivit se dá teorie self-efficacy aplikovat následovně. Pokud bude mít učitel tělesné výchovy dostatečnou sebedůvěru ve vlastní schopnosti pro uskutečnění integrace žáka se zdravotním postižením (ZP) do hodin tělesné výchovy, tak se o to pokusí (dojde ke konfrontaci s jeho faktickými dovednostmi). Vezmeme-li prríklad dvou učitelů tělesné výchovy, kteří mají stejnou (nebo velmi podobnou) úroveň dovedností, ale odlišnou úroveň self-efficacy. Učitel s vyšší úrovní self-efficacy se s větší pravděpodobností pokusí o integraci (přizpůsobit výuku tak, aby byl zajištěn pozitivní vliv) žáka se ZP do hodin tělesné výchovy než učitel s nižší úrovní self-efficacy. Zároveň učitel s vyšší úrovní self-efficacy bude mít větší vytrvalost ve svém úsilí provést daný úkol, i když se setká s problémy, které nepředpokládal (Block et al., 2013).

Dotazník, jehož datum uvedení se váže na rok 2013, je produktem mezinárodní spolupráce Američana Martina Blocka, Lotyšky Aiji Klaviny a Izraelců Yeshayahu Hutzlera a Sharona Baraka. Samotný dotazník se dělí do čtyř částí. V první, druhé a třetí části je vždy nejdříve uveden popis žáka se zdravotním postižením. U první části jde o žáka s mentálním postižením, ve druhé části je to žák s tělesným postižením a ve třetí části žák se zrakovým postižením. Poté v každé z těchto tří částí následuje 
série otázek (celkem jde o třicet tři otázek, přičemž v první části je otázek jedenáct, ve druhé dvanáct a ve třetí deset), které se týkají sebedůvěry respondenta ve vlastní kompetence při integraci daného zdravotně postiženého žáka do hodin školní tělesné výchovy. Otázky jsou zaměřeny na sebedůvěru ve vlastní kompetence při modifikaci obsahu hodin, vedení, zajišt'ování bezpečnosti a dovednosti instruovat intaktní spolužáky pro peer tutoring. Pětistupňové škálovací otázky zjišt’ují míru sebedůvěry ve vlastní kompetence, kdy 1 znamená „,bez důvěry“, 2 „nízká důvěra“, 3 „střední důvěra“, 4 ,vysoká důvěra“ a 5 ,úplná důvěra“. Čtvrtá část dotazníku obsahuje sérii doplňujících otázek (autoři tuto část nazvali demographic questions), která zjišt'uje respondentův věk, pohlaví, studijní ročník, zkušenosti s teoretickými předměty a absolvovanou praxi v oblasti aplikovaných pohybových aktivit.

Vzorek, kterému byla předložena americká verze dotazníku, čítal 486 respondentů, přičemž šlo o studenty prvních až pátých ročníku tělesné výchovy, kteří měli rozdílné zkušenosti (někteří téměř nulové) s výukou aplikované tělesné výchový. Z celkového počtu 486 účastníků bylo 170 ženského pohlaví a 316 mužského pohlaví.

Analýza dat proběhla v několika krocích. Obsahová validita byla stanovena deseti americkými a evropskými univerzitními pedagogy a pěti absolventy studia aplikované tělesné výchovy. Nejprve proběhlo posouzení konstrukční validity s využitím faktorové analýzy. U všech dotazníků bylo provedeno zpracování dat samostatně pro všechny tři subškály (zvlášt’ pro každé postižení). Soudržnost jednotlivých položek byla zjišt'ována pomocí Cronbach analýzy a po zpracování se pohybovala od 0,73 do 0,89 . Vnitřní konzistence je pro část mentální postižení 0,86; pro tělesné postižení 0,90 a pro zrakové postižení 0,92 .

Autoři naznačují, že v dalším výzkumu by bylo zajímavé zjištovat jaké specifické informace, literatura či praktické zkušenosti mají vliv na míru úrovně self-efficacy při začleňování žáků se zdravotním postižením do hodin školní tělesné výchovy. Zároveň by bylo přínosné zjistit formou rozhovorů, jaký typ informace či zkušenosti měl pro studenty největší význam. 
The results of the pilot study of questionnaire SE-PETE-D, which checks the trust of students of physical education...

Výsledky pilotní studie dotazníku SE-PETE-D, který zjištuje důvěru studentů učitelství tělesné výchovy v jejich...

\section{Výsledky pilotní studie}

Výsledky obou sledovaných skupin jsou porovnány v tabulkách 1 , 2 a 3, přičemž každá položka zjišstující úroveň self-efficacy je vyhodnocena samostatně. $Z$ výsledků je patrné, že námi stanovená hypotéza „Studenti aplikovaných pohybových aktivit budou mit vyšši self-efficacy pro realizaci výuky integrované tělesné výchovy (se zaměrením na osoby s mentálním, tělesným a zrakovým postižením) než studenti tělesné výchovy " byla potvrzena. Ze 33 sledovaných položek měli studenti APA vyšší průměrnou úroveň self-efficacy ve všech 33 prrípadech. U 15 ze 33 položek byla statistická významnost nižší než 0,05 . Přesněji šlo o 8 položek z 12 u tělesného postižení, 6 položek z 11 u mentálního postižení a 1 položka z 10 u zrakového postižení.

\section{ZÁVĚR}

Dotazník SE-PETE-D je podle autorů tohoto př́spěvku vhodným nástrojem zjišt’ujícím self-efficacy pro realizaci výuky integrované tělesné výchovy. Zároveň se autoři domnívají, že jde o potřebný měřící nástroj, který pomůže ke zkvalitnění výuky předmětů z oblasti aplikovaných pohybových aktivit na českých vysokých školách. $Z$ těchto důvodů započali náročný proces restandardizace zmíněného dotazníku do podmínek českého prostředí, jehož první výsledky jsou prezentovány $\mathrm{v}$ tomto př́spěvku.

Předkládané výsledky pilotní studie potvrzují naši hypotézu, tedy že studenti aplikovaných pohybových aktivit mají vyšší úroveň self-efficacy pro práci v integrované tělesné výchově než studenti učitelství tělesné výchovy. Zároveň dotazník prokázal u studentů senzitivitu pro zjištování self-efficacy ve vztahu k realizaci integrované tělesné výchovy.

$\mathrm{V}$ následujícím kroku budeme ověřovat validitu a reliabilitu dotazníku (SE-PETE-D). Proto bychom chtěli oslovit partnerské katedry tělesné výchovy v Plzni (Pedagogická fakulta, Západočeská univerzita) a v Ústí nad Labem (Pedagogická fakulta, Univerzita J. E. Purkyně) a jejich studenty při participaci na tomto procesu. 


\section{LITERATURA}

Bandura, A. (1989). Social cognitive theory. In R. Vasta (Ed.), Annals of child development. Vol. 6. Six theories of child development (pp. 1-60). Retrieved 20. 9. 2013 from the Word Wide Web: http:// www.uky.edu/ eushe2/Bandura/Bandura1989ACD.pdf.

Bandura, A. (1997). Self-efficacy: the exercise of control. New York: W. H. Freeman.

Banville, D., Desrosiers, P., \& Genet-Volet, Y. (2000). Translating questionnaires and inventories using a cross-cultural translation technique. Journal of Teaching in Physical Education, 19, 374-387.

Blatný, M. a kol. (2010). Psychologie osobnosti: hlavní témata, současné prístupy. Praha: Grada Publishing.

Block, M. E., Hutzler, Y., Barak, S. \& Klavina, A. (2013). Creation and Validation of the Self_Efficacy Instrument for Physical Education Teacher Education Majors towards inclusion. Adapted Physical Aktivity Quarterly, 30 (2), 184-205.

Čurdová, J. (2002). Volnočasové pohybové aktivity osob s postižením. In B. Hodaň (Ed.), Volný čas a jeho současné problémy. Sborník přispěvků prednesených na vědeckém symposiu v Olomouci ve dnech 20. a 21. května 2000 (pp. 110-118). Olomouc: Hanex.

Janoušek, J. (1992). Sociálně kognitivní teorie Alberta Bandury. Československá psychologie, 36 (5), 385-398.

Janoušek, J (2006). Aspirační úroveň, výkonový motiv a vnímané sebeuplatnění jako psychologické faktory výkonnosti ve společenských podmínkách. Pražské sociálně vědní studie - Psychologická řada. Fakulta sociálních věd Univerzity Karlovy.

Karásková, V. (2005). Kapitoly z teorie a didaktiky aplikované tělesné výchovy. Olomouc: Univerzita Palackého.

Kudláček, M. (1997). Integrace osob na vozíku prostřednictvím pohybových aktivit. Diplomová práce. Olomouc: Univerzita Palackého, Fakulta tělesné kultury.

Kursová, V. (2009). Rozvoj zdraví a integrace osob s mentálním postižením pomocí cílených pohybových aktivit: Otevřený pohybový intervenční program. České Budějovice: Jihočeská univerzita. 
Výsledky pilotní studie dotazníku SE-PETE-D, který zjištuje důvěru studentů učitelství tělesné výchovy v jejich...

Nakonečný, M. (1998). Psychologie osobnosti. Praha: Akademia.

Spurná, M., Rybová, L. \& Kudláček, M. Participace žáků s tělesným postižením v integrované školní tělesné výchově. Aplikované pohybové aktivity v teorii a praxi, 1 (1), 33-38.

Tod, D., Thatcher, J. \& Rahman, R. (2012). Psychologie sportu. Praha: Grada Publishing.

Urbánek, T. \& Čermák, I. (1997). Vliv self-efficacy na agresi a depresi u dětí. Československá psychologie, 41 (3), 193-199.

Vallerand, R. J. (1989). Vers une méthodologie de validation transculturelle de questionnaires psychologiques: implications pour la recherche en langue françoise [Toward a methodology of cross-cultural validation of psychological questionnaires: Implications for research in French]. Psychologie Canadienne, 30, 662-680.

Vágnerová, M., Hajd-Moussová, Z., \& Štech, S. (2001). Psychologie handicapu. Praha: Karolinum.

Válková, H. (2011). Aplikované pohybové aktivity v univerzitním studiu. Aplikované pohybové aktivity v teorii a praxi, 2 (1), 29-41.

Votava, J. a kol. (2003). Ucelená rehabilitace osob se zdravotním postižením. Praha: Karolinum.

\section{KONTAKT:}

Mgr. Ladislav Baloun, balola00@upol.cz 


\section{P̌̌́́LOHA}

Tab. 1: Výsledky t-testu pro položky u mentálního postižení

\begin{tabular}{|c|c|c|c|c|}
\hline Položka & M APA* & M TV** & T-test & Sig.*** \\
\hline $1 \mathrm{a}$ & 3,43 & 2,71 & 2,97 & $<0,01$ \\
\hline $1 \mathrm{~b}$ & 3,67 & 3,36 & 1,05 & 0,30 \\
\hline $1 \mathrm{c}$ & 3,71 & 3,64 & 0,28 & 0,78 \\
\hline $1 \mathrm{~d}$ & 3,57 & 3,00 & 1,90 & 0,07 \\
\hline $1 \mathrm{e}$ & 3,29 & 2,64 & 2,42 & 0,02 \\
\hline $1 \mathrm{f}$ & 3,57 & 2,93 & 2,28 & 0,03 \\
\hline $1 \mathrm{~g}$ & 3,52 & 2,86 & 2,32 & 0,03 \\
\hline $1 \mathrm{~h}$ & 3,81 & 3,29 & 2,05 & 0,05 \\
\hline $1 \mathrm{i}$ & 3,24 & 2,79 & 1,47 & 0,15 \\
\hline $1 \mathrm{j}$ & 3,05 & 2,64 & 1,68 & 0,10 \\
\hline $1 \mathrm{k}$ & 3,57 & 3,00 & 2,62 & 0,01 \\
\hline
\end{tabular}

Legenda: *MAPA-prưměrně dosažené skóre u studentů aplikovaných pohybových aktivit; **M TV-prüměrně dosažené skóre u studentů tělesné výchovy; ***Sig - signifikance.

Tab. 2: Výsledky t-testu pro položky u tělesného postižení

\begin{tabular}{|c|c|c|c|c|}
\hline Položka & M APA $^{*}$ & M TV $^{* *}$ & T-test & Sig. $^{* * *}$ \\
\hline $2 \mathrm{a}$ & 3,52 & 2,93 & 1,65 & 0,11 \\
\hline $2 \mathrm{~b}$ & 3,67 & 2,71 & 2,92 & 0,01 \\
\hline $2 \mathrm{c}$ & 3,95 & 3,43 & 1,84 & 0,07 \\
\hline $2 \mathrm{~d}$ & 4,00 & 3,07 & 3,07 & $<0,01$ \\
\hline $2 \mathrm{e}$ & 3,29 & 2,79 & 1,46 & 0,16 \\
\hline $2 \mathrm{f}$ & 3,86 & 2,50 & 4,81 & $<0,01$ \\
\hline $2 \mathrm{~g}$ & 3,43 & 2,79 & 2,04 & 0,05 \\
\hline $2 \mathrm{~h}$ & 3,90 & 3,43 & 1,72 & 0,10 \\
\hline $2 \mathrm{i}$ & 3,71 & 2,50 & 3,70 & $<0,01$ \\
\hline $2 \mathrm{j}$ & 3,71 & 2,64 & 3,28 & $<0,01$ \\
\hline $2 \mathrm{k}$ & 3,48 & 2,36 & 3,62 & $<0,01$ \\
\hline $2 \mathrm{l}$ & 3,95 & 3,21 & 2,66 & 0,01 \\
\hline
\end{tabular}

Legenda: *MAPA-průměrně dosažené skóre u studentů aplikovaných pohybových ak- 
The results of the pilot study of questionnaire SE-PETE-D, which checks the trust of students of physical education...

Výsledky pilotní studie dotazníku SE-PETE-D, který zjištujuje důvěru studentů učitelství tělesné výchovy v jejich...

tivit; **M TV-průměrně dosažené skóre u studentů tělesné výchovy; ***Sig - signifikance.

Tab. 3: Výsledky t-testu pro položky u zrakového postižení

\begin{tabular}{|c|c|c|c|c|}
\hline Položka & M APA* $^{*}$ & M TV $^{* *}$ & T-test & Sig.*** $^{* * 1}$ \\
\hline $3 \mathrm{a}$ & 3,67 & 3,00 & 1,83 & 0,08 \\
\hline $3 \mathrm{~b}$ & 3,81 & 3,64 & 0,52 & 0,61 \\
\hline $3 \mathrm{c}$ & 3,62 & 3,29 & 0,95 & 0,35 \\
\hline $3 \mathrm{~d}$ & 3,52 & 3,21 & 0,98 & 0,33 \\
\hline $3 \mathrm{e}$ & 3,52 & 3,43 & 0,28 & 0,78 \\
\hline $3 \mathrm{f}$ & 3,62 & 3,07 & 1,73 & 0,09 \\
\hline $3 \mathrm{~g}$ & 3,57 & 2,79 & 2,50 & 0,02 \\
\hline $3 \mathrm{~h}$ & 3,19 & 2,57 & 1,62 & 0,12 \\
\hline $3 \mathrm{i}$ & 3,71 & 3,36 & 1,13 & 0,27 \\
\hline $3 \mathrm{j}$ & 3,33 & 3,07 & 0,75 & 0,46 \\
\hline
\end{tabular}

Legenda: *M APA - průmérně dosažené skóre u studentů aplikovaných pohybových aktivit; **M TV-průměrně dosažené skóre u studentů tělesné výchovy; ***Sig - signifikance. 